\title{
CASE STUDY OF THE EVALUATION OF THE LIFE CYCLE OF A FACADE USING THE FLIP TEACHING METHOD
}

\author{
N. Ata-Ali, D. Martínez-Muñoz, V. Yepes, J.V. Martí \\ ICITECH. Dept. Ingeniería de la Construcción y Proyectos de Ingeniería Civil. Universitat \\ Politècnica de València (SPAIN)
}

\begin{abstract}
In the constant search for new and innovative pedagogical strategies, a model of teaching is proposed in which the learning of the student and the acquisition of all possible skills is the main thing. This article shows the study carried out by students of the subject "Methods and Advanced Technologies in work", taught in the Master's Degree in Planning and Management in Civil Engineering (MAPGIC) of the Universitat Politècnica de València. By means of the "flip teaching" or "flipped classroom" technique, students carry out the evaluation of the life cycle of a type of facade enclosure. This method gives students the responsibility to review the theoretical content so that they can solve their doubts and work on the concepts in class, individually or collaboratively way, as well as knowing, understanding and applying constructive procedures to advanced construction works. In Addition, it will acquire transversal competencies, such as decision-making and problem-solving capacities in terms of designs and projects to be carried out, taking into account ethical, environmental and professional responsibility.
\end{abstract}

Keywords: technological resources, tools, active methodology, inverse class, life cycle.

\section{INTRODUCTION}

As a consequence of the Bologna Declaration [1], the higher education system has undergone a major change in recent years. In this agreement, the Ministers of Education of various European countries, both within the EU and outside it, issued a joint declaration that gave rise to a convergence process aimed at facilitating the exchange of graduates and adapting the content of university studies to social demands, improving their quality and competitiveness through greater transparency and quality of learning.

The Bologna process, although not a binding treaty, led to the creation of the European Higher Education Area, an area that serves as a frame of reference for the educational reforms that many countries would have to initiate in the early years of the 21st century. Competitiveness, mobility, and employability are fostered through a new teaching model that focuses on the acquisition of skills rather than the acquisition of knowledge.

Focusing on the pedagogical conception [2], we find two groups, teaching as the transmission of knowledge and teaching as an aid for learning. Teaching as a transmission of knowledge enables students to be passive recipients of the information provided to them. However, teaching as an aid for learning is based on encouraging students to continue developing their learning through a more participative and active role in the entire educational process [3].

More technical professions, such as engineer or architect, are always linked to problem-solving analysis, always towards a very deductive teaching trend. This is changing, and we are beginning to opt for learning by competencies. An example is the Higher Technical School of Civil Engineering of the Polytechnic University of Valencia, where methodologies such as "flip teaching", are proposed and promoted, where the traditional teaching model is inverted and teachers teach using much more attractive content, much more motivating techniques, and always with the guarantee of being able to offer a much higher level of learning to each of their students. In addition, students are responsible for reviewing the theoretical content at home so that they can then resolve their doubts and work on the concepts in the classroom individually or collaboratively.

The EXCELCON Educational Innovation and Quality Team is based on the management of projects and construction, as well as on the research of different techniques applied to engineering education. [4-7]. The research group has carried out several studies related to multi-criteria decision-making and/or heuristic techniques in the field of engineering $[8,9]$. In addition, other types of studies have been undertaken, such as the evaluation of tools and active methodologies in the degree and in the evaluation of different transversal competencies, such as critical thinking, to the studies of the most technical 
branch of engineering [10-13] without setting aside the students' awareness of sustainability [14]. The group has also researched practical examples related to the optimization of walls [15, 16].

All these studies are framed within the subjects of "Typologies and Procedures of the Constructions of the I.C.", belonging to the degree of Public Works Engineering, "Predictive Models and Optimization of Concrete Structures" of the Master's in Concrete Engineering, and "Advanced Methods and Technology in Construction", taught in the University Master's in Planning and Management in Civil Engineering (MAPGIC), all offered by the Polytechnic University of Valencia. [17-20]

The goal of this paper is to show the technological resources and tools used in "Advanced Methods and Technology in Construction ", taught in the MAPGIC. Furthermore, this paper also provides an evaluation of the life cycle of a facade enclosure by students using the tools and resources provided that are part of the active methodology in the learning process.

\section{METHODOLOGY}

So that students could carry out the proposed facade life cycle assessment exercise correctly, they were provided with a series of technological tools and resources.

Among them, the following stand out:

- PoliformaT resources tool: Where the documentation of all the subject is found and the student can find all the necessary information for learning. This documentation not only covers the subjects to be taught in class but also on annexes and complementary information, as well as a bibliography, to complete their training.

- Slides in pdf and PowerPoint: For better organization of all the topics that are part of the subject, the teacher makes a series of slides in different formats so that the student has more detail on each topic. Images and examples of practical cases are provided to help and guide the student.

- Polimedia Videos: The videos are an educational technology that is based on explanations recorded by the teacher, which interact indirectly with the student, who pause at any time to take notes and gain a greater understanding of the content.

- Lessons: So that the student knows the planning related to the subject, including the topics that are going to be seen every day, the documentation that they need, and the preparatory activities must be carried out both at home and in the classroom, they have the lessons tool. This tool is a clear example of active methodologies such as the "flip teaching".

All these resources are useful for carrying out this education and learning methodology. Reverse pedagogy or flip teaching is a new method that proposes turning the traditional class around and reversing the order in the learning process, as opposed to the usual teaching model where the teacher explains the lesson in class and the students listen and do their homework at home. The student is offered the opportunity to value the content they are given and to be protagonists in their learning process without the teacher being the center at all times. However, the teacher will always be a guide and will act as a coordinator in real-time, answering all the questions that arise. The students' work will be supervised, evaluating how they have carried it out. Finally, the teacher will transfer to the students' different questions, short and direct, to assimilate and evaluate the learning process of each student.

\subsection{Case study}

Once all the objectives were set and knowing that the student has all that is needed to develop their learning, they were tasked with carrying out the cycle evaluation of a facade enclosure using the Open LCA software and the Ecoinvent database [21-22]. We assumed that the façades were located in two Spanish cities with different climatology such as Ávila and Valencia. The students analyzed the four phases of production, construction, use, and end of life to analyze and calculate the environmental impact of the construction of a square meter of a façade, comparing the results in both cities.

Uncertainty was considered in each of the analyzed phases and was done through the pedigree matrix, in addition to performing a Monte Carlo analysis with 1000 simulations. The obtained values were shown using graphs, as they facilitate comparing the results [23-25] 


\section{RESULTS}

The results obtained by the students when doing the practical exercise using the "flip teaching" method have been very positive. They used the tools and resources provided to them and managed to learn how to use the required computer program, in addition to knowing how to interpret the results obtained through it. These results are shown below [26-28].

If we focus on Tables 1 and 2, we can see that, of the 18 impact categories, the city of Ávila causes around $50 \%$ more environmental impact than Valencia in the vast majority of impacts, ALO, CC, FD, HT, and IR. The façade located in Ávila that presents a construction section with double the thickness of thermal insulation compared to Valencia is responsible.

Table 1. Façade impacts. Average value and coefficient of variation (cv)

\begin{tabular}{|c|c|c|c|c|c|}
\hline & & Valencia & & Ávila & \\
\hline Impact Category & Unit & Mean & $\operatorname{cv}(\%)$ & Mean & $\operatorname{cv}(\%)$ \\
\hline Agricultural land occupation & $\mathrm{m}^{2 *} \mathrm{a}$ & 9.36114766 & $39 \%$ & 9.86265972 & $36 \%$ \\
\hline Climate Change & $\mathrm{kg} \mathrm{CO} 2 \mathrm{eq}$ & 118.307565 & $11 \%$ & 132.339269 & $12 \%$ \\
\hline Fossil depletion & $\mathrm{kg}$ oil eq & 32.6656477 & $12 \%$ & 36.5040711 & $12 \%$ \\
\hline Freshwater ecotoxicity & kg 1,4-DB eq & 1.41605638 & $12 \%$ & 1.53566185 & $12 \%$ \\
\hline Freshwater eutrophication & $\mathrm{kg} \mathrm{P}$ eq & 0.02716613 & $13 \%$ & 0.0305368 & $14 \%$ \\
\hline Human toxicity & $\mathrm{kg} 1,4-\mathrm{DB}$ eq & 30.6459122 & $15 \%$ & 34.4859547 & $14 \%$ \\
\hline lonizing radiation & $\mathrm{kg} \mathrm{U}_{235} \mathrm{eq}$ & 7.3608334 & $11 \%$ & 8.10650884 & $11 \%$ \\
\hline Marine ecotoxicity & kg 1,4-DB eq & 1.28235004 & $12 \%$ & 1.39926817 & $12 \%$ \\
\hline Marine eutrophication & $\mathrm{kg} \mathrm{N}$ eq & 0.05398696 & $34 \%$ & 0.05638602 & $32 \%$ \\
\hline Metal depletion & $\mathrm{kg} \mathrm{Fe} \mathrm{eq}$ & 6.0349623 & $24 \%$ & 6.5887318 & $20 \%$ \\
\hline Natural land transformation & $\mathrm{m}^{2}$ & 0.03057513 & $13 \%$ & 0.03547028 & $14 \%$ \\
\hline Ozone depletion & kg CFC-11eq & 1.2839E-05 & $12 \%$ & 1.4147E-05 & $12 \%$ \\
\hline Particulate matter formation & $\mathrm{kg} \mathrm{PM}_{10} \mathrm{eq}$ & 0.36424223 & $26 \%$ & 0.39511239 & $21 \%$ \\
\hline Photochemical oxidant formation & kg NMVOC & 0.46663837 & $11 \%$ & 0.51666851 & $13 \%$ \\
\hline Terrestrial acidification & $\mathrm{kg} \mathrm{SO}_{2}$ eq & 0.5480577 & $12 \%$ & 0.62818589 & $15 \%$ \\
\hline Terrestrial ecotoxicity & $\mathrm{kg} 1,4-\mathrm{DB}$ eq & 0.20565172 & $61 \%$ & 0.20691243 & $59 \%$ \\
\hline Urban land occupation & $\mathrm{m}^{2 *} \mathrm{a}$ & 1.30347537 & $18 \%$ & 1.55108553 & $17 \%$ \\
\hline Water depletion & $\mathrm{m}^{3}$ & 334.172049 & $10 \%$ & 356.622044 & $10 \%$ \\
\hline
\end{tabular}

We can observe that other impact categories, such as PMF, TAC, TEC, and ULO, were not as affected by the difference in the increase in the thermal insulation thickness.

Table 2. Façade impacts

\begin{tabular}{|l|c|c|}
\hline \multicolumn{1}{|c|}{ Impact Category } & Valencia & Ávila \\
\hline Agricultural land occupation (ALO) & $48.88 \%$ & $94.61 \%$ \\
\hline Climate Change (CH) & $48.39 \%$ & $99.60 \%$ \\
\hline Fossil depletion (FD) & $48.64 \%$ & $98.54 \%$ \\
\hline Freshwater ecotoxicity (FEC) & $48.73 \%$ & $74.45 \%$ \\
\hline Freshwater eutrophication (FEU) & $91.38 \%$ & $2.98 \%$ \\
\hline Human toxicity (HT) & $48.11 \%$ & $98.47 \%$ \\
\hline lonizing radiation (IR) & $48.93 \%$ & $93.75 \%$ \\
\hline Marine ecotoxicity (MEC) & $48.72 \%$ & $72.57 \%$ \\
\hline Marine eutrophication (MEU) & $49.16 \%$ & $9.28 \%$ \\
\hline Metal depletion (MD) & $48.83 \%$ & $92.17 \%$ \\
\hline Natural land transformation (NLT) & $47.87 \%$ & $6.19 \%$ \\
\hline Ozone depletion (OD) & $49.33 \%$ & $0.00 \%$ \\
\hline Particulate matter formation (PMF) & $48.43 \%$ & $42.43 \%$ \\
\hline Photochemical oxidant formation (POF) & $48.28 \%$ & $49.81 \%$ \\
\hline Terrestrial acidification (TA) & $47.37 \%$ & $54.93 \%$ \\
\hline Terrestrial ecotoxicity (TEC) & $49.97 \%$ & $25.90 \%$ \\
\hline Urban land occupation (ULO) & $48.52 \%$ & $72.38 \%$ \\
\hline Water depletion (WD) & $48.85 \%$ & $99.86 \%$ \\
\hline
\end{tabular}


If we look at the following graphs, Figures 1-6, we can see the overall result in the three categories of resources, human health, and ecosystem. All were analyzed in each of the phases studied.

\section{RESOURCES}

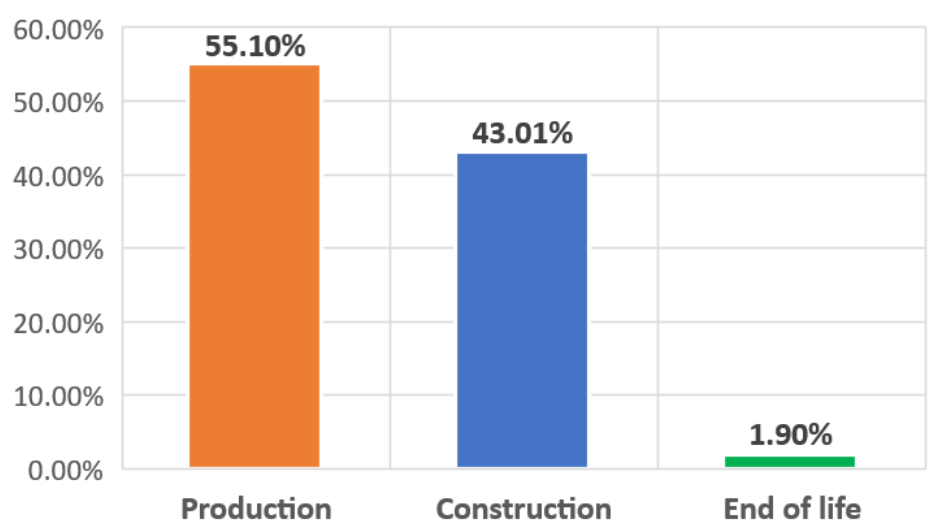

Figure 1. Ávila city impacts (Resources)

\section{HUMAN HEALTH}

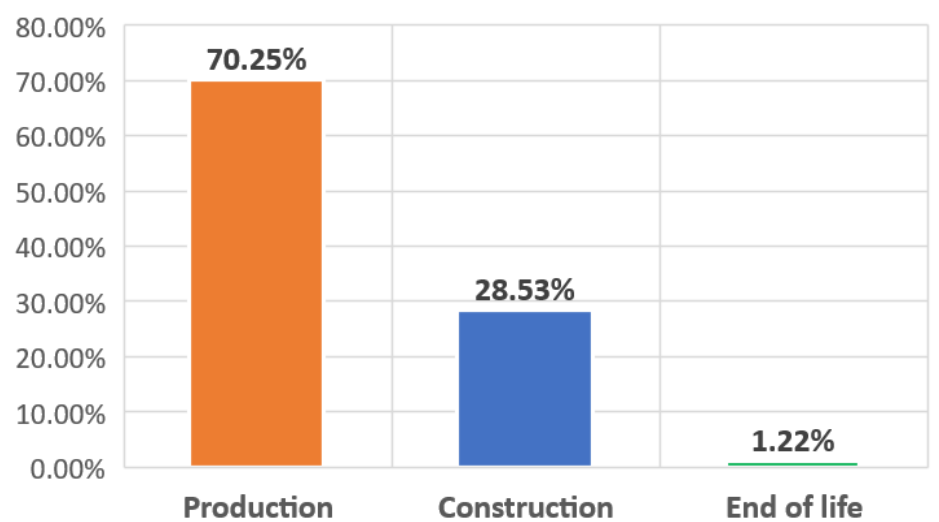

Figure 2. Ávila city impacts (Human Health)

\section{ECOSYSTEMS}

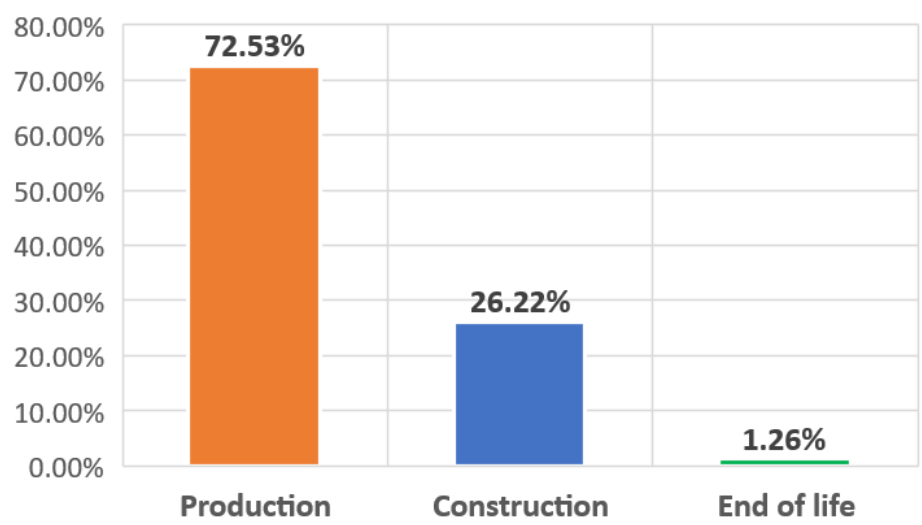

Figure 3. Ávila city impacts (Ecosystem) 


\section{RESOURCES}

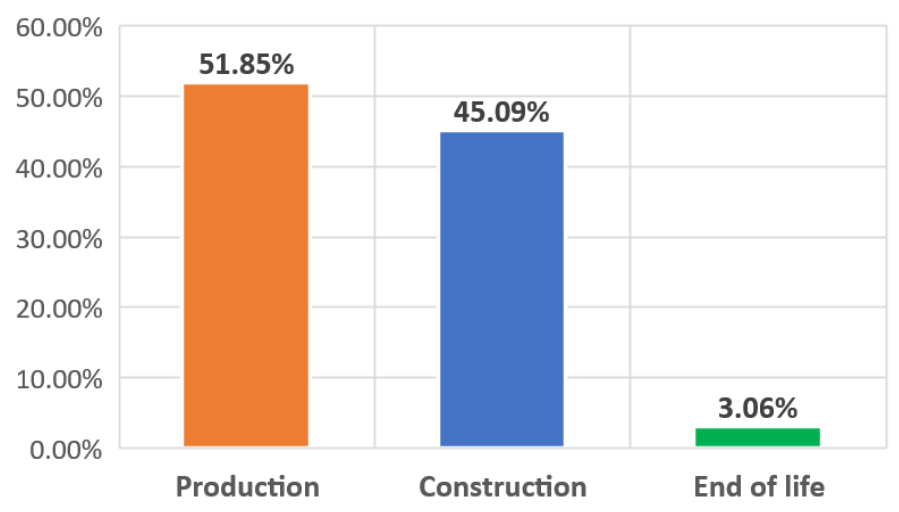

Figure 4. Valencia city impacts (Resources)

HUMAN HEALTH

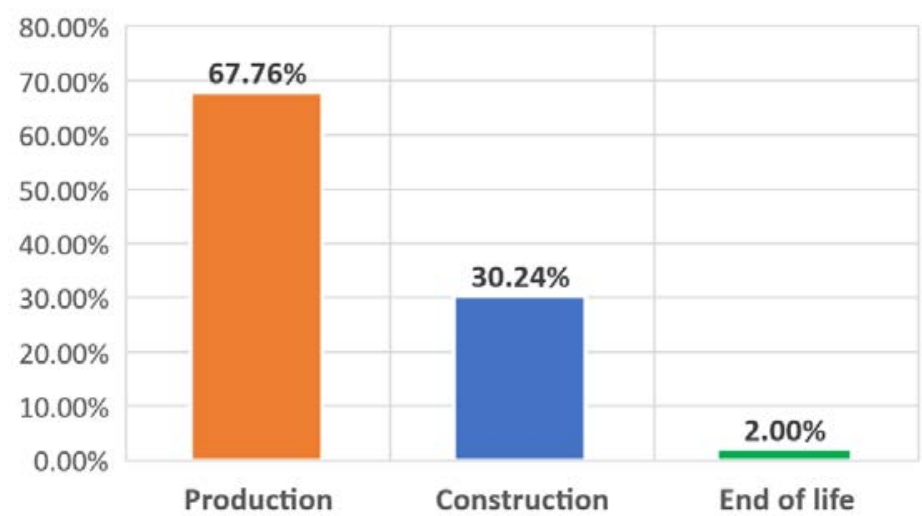

Figure 5. Valencia city impacts (Human Health)

ECOSYSTEMS

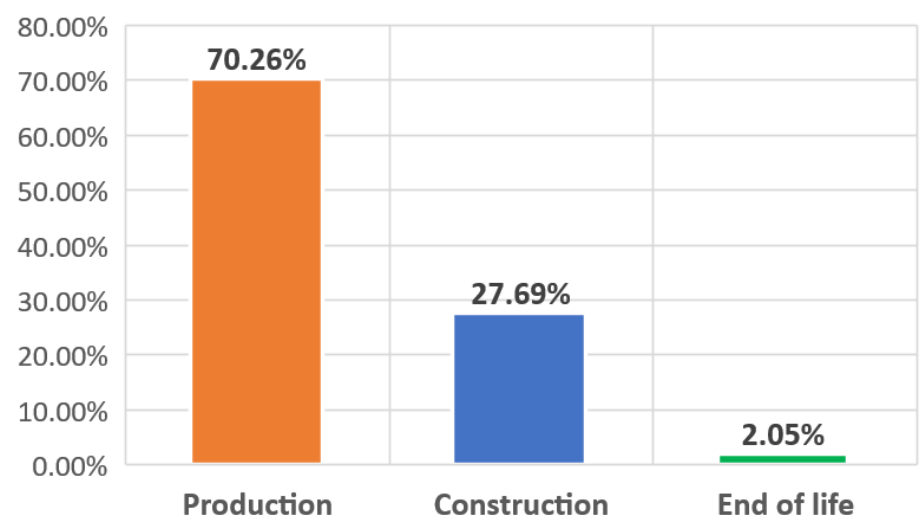

Figure 6. Valencia city impacts (Ecosystems)

The results show that the most important phase, with the greatest impact in both cities, is the production phase, exceeding $50 \%$ of the total in all three categories analyzed.

\section{CONCLUSIONS}

This communication presents a practical case made by students in the "Advanced Methods and Technology in Construction" course following the "flip teaching" methodology.

The students learned how to use the Open LCA software with the Ecoinvent database in addition to knowing the importance of choosing the right type of facade construction system and the different 
materials most are appropriate to achieve a lower environmental impact. With the tools and resources that provided, they acquired the necessary knowledge to develop the practical exercise that was proposed to them with total security. At the end of the deadline for this exercise, the class carried out collective correction and sharing of all the doubts that arose during the execution process.

\section{ACKNOWLEDGMENTS}

The authors are grateful for the support received by the Ministry of Economy, and Business and FEDER funds (Research Project BIA2017-85098-R) and the Universitat Politècnica de València (EXCELCON Educational Innovation and Quality Team).

\section{REFERENCES}

[1] BOLOGNA DECLARATION (1999). "Towards the European Higher European Area". Conference of Ministers responsible for Higher Education in 29 European countries. June, Bologna, Italy.

[2] G KEMBER, D., KWAN, K.P. y LEDESMA, J. (2001). "Conceptions of good teaching and how they influence the way adults and school leavers are taught", International Journal of Lifelong Education, vol. 20, issue 5, p. 393-404.

[3] KANE, L. (2004). "Educators, learners and active learning methodologies", International Journal of Lifelong Education, vol. 23, issue 3, p. 275-286.

[4] YEPES, V.; DASÍ-GIL, M.; MARTÍNEZ-MUÑOZ, D.; LÓPEZ-DESFILÍS, V.J.; MARTÍ, J.V. (2019). Heuristic techniques for the design of steel-concrete composite pedestrian bridges. Applied Sciences, 9, 3253; DOI:10.3390/app9163253

[5] PENADÉS-PLÀ, V.; GARCÍA-SEGURA, T.; YEPES, V. (2019). Accelerated optimization method for low-embodied energy concrete box-girder bridge design. Engineering Structures, 179:556-565. DOI: 10.1016/j.engstruct.2018.11.015

[6] NAVARRO, I.J.; YEPES, V.; MARTÍ, J.V. (2019). A review of multi-criteria assessment techniques applied to sustainable infrastructures design. Advances in Civil Engineering, 2019: 6134803. DOI:10.1155/2019/6134803

[7] NAVARRO, I.J.; YEPES, V.; MARTÍ, J.V.; GONZÁLEZ-VIDOSA, F. (2018). Life cycle impact assessment of corrosion preventive designs applied to prestressed concrete bridge decks. Journal of Cleaner Production, 196: 698-713. DOI: 10.1016/j.jclepro.2018.06.110

[8] NAVARRO, I.J.; YEPES, V.; MARTÍ, J.V. (2018). "Heuristics in engineering education. A case study application to sustainable bridge management systems", Proceedings of ICERI 2018, the 11th annual International Conference of Education, Research and Innovation, Seville (Spain), 12th-14th November 2018, pp. 9788-9797.

[9] NAVARRO, I.; MARTÍ, J.V.; YEPES, V. (2018). "Multi-criteria decision making techniques in civil engineering education for sustainability", Proceedings of ICERI2018 the 11th annual International Conference of Education, Research and Innovation, Seville (Spain), 12th-14th November 2018, pp. 9798-9807.

[10] GARCÍA-SEGURA, T.; MARTÍ, J.V.; YEPES, V. (2017a). "Valoración de las herramientas y metodologías activas en el Grado en Ingeniería de Obras Públicas". Congreso Nacional de Innovación Educativa y de Docencia en Red IN-RED 2017, Valencia, 13 y 14 de julio de 2017, 9 $\mathrm{pp}$.

[11] GARCÍA-SEGURA, T.; YEPES, V.; MOLINA-MORENO, F.; MARTí, V. (2017b). "Assessment of transverse and specific competences in civil engineering studies: 'Critical thinking'". 11th annual International Technology, Education and Development Conference (INTED 2017), Valencia, 6th, 7th and 8th of March, 2017, pp. 3683-3692.

[12] YEPES, V., MARTI, J.V. y GARCÍA-SEGURA, T. (2016). "Desarrollo y evaluación de la competencia transversal "pensamiento crítico" en el grado de ingeniería civil". En: Jornadas de Innovación Educativa y Docencia en Red IN-RED 2016. 7-8 de julio, Valencia, pp. 1-14. 
[13] YEPES, V.; MARTÍ, J.V.; MOLINA-MORENO, F. (2017). "Transverse competence 'critical thinking' in civil engineering graduate studies: preliminary assessment". 11th annual International Technology, Education and Development Conference (INTED 2017), Valencia, 6th, 7th and 8th of March 2017, pp. 2639-2649.

[14] PELLICER, E.; SIERRA, L.A.; YEPES, V. (2016). Appraisal of infrastructure sustainability by graduate students using an active-learning method. Journal of Cleaner Production, 113:884-896. DOI: 10.1016/j.jclepro.2015.11.010

[15] MARTÍ, J.V.; YEPES, V.; MOLINA-MORENO, F. (2017). "Simulated annealing with parameter tuning for energy optimization of retaining walls. A case study application in education". 11th annual International Technology, Education and Development Conference (INTED 2017), Valencia, 6th, 7th and 8th of March 2017, 2368-2378.

[16] MOLINA-MORENO, F.; MARTÍ, J.V.; YEPES, V. (2017). "Assessment of the argumentative ability in innovation management of civil engineering studies". 11th annual International Technology, Education and Development Conference (INTED 2017), Valencia, 6th, 7th and 8th of March 2017, pp. 3904-3913

[17] PELLICER, E.; CORREA, C.L.; YEPES, V.; ALARCÓN, L.F. (2012). Organizational improvement through standardization of the innovation process in construction firms. EMJ-Engineering Management Journal, 24(2): 40-53. DOI: 1080/10429247.2012.11431935

[18] YEPES, V.; PELLICER, E.; ORTEGA, J.A. (2012). Designing a benchmark indicator for managerial competences in construction at the graduate level. Journal of Professional Issues in Engineering Education and Practice, 138(1): 48-54. DOI:10.1061/(ASCE)EI.1943-5541.0000075

[19] PELLICER, E.; YEPES, V.; CORREA, C.L.; ALARCÓN, L.F. (2014). Model for Systematic Innovation in Construction Companies. Journal of Construction Engineering and Management, 140(4):B4014001. DOI:10.1061/(ASCE)CO.1943-7862.0000468

[20] TORRES-MACHÍ, C.; CARRIÓN, A.; YEPES, V.; PELLICER, E. (2013). Employability of graduate students in construction management. Journal of Professional Issues in Engineering Education and Practice, 139(2):163-170. DOI:10.1061/(ASCE)El.1943-5541.0000139

[21] NAVARRO, I.J.; YEPES, V.; MARTÍ, J.V. (2018). Social life cycle assessment of concrete bridge decks exposed to aggressive environments. Environmental Impact Assessment Review, 72:50-63. DOI: 1016/j.eiar.2018.05.003

[22] PENADÉS-PLÀ, V.; GARCÍA-SEGURA, T.; MARTí, J.V.; YEPES, V. (2018). An optimization-LCA of a prestressed concrete precast bridge. Sustainability, 10(3):685. DOI:3390/su10030685

[23] SIERRA, L.A.; PELLICER, E.; YEPES, V. (2016). Social sustainability in the life cycle of Chilean public infrastructure. Journal of Construction Engineering and Management, 142(5):05015020. DOI:10.1061/(ASCE)CO.1943-7862.0001099

[24] CARBONELL, A.; GONZÁLEZ-VIDOSA, F.; YEPES, V. (2011). Design of reinforced concrete road vaults by heuristic optimization. Advances in Engineering Software, 42(4): 151-159. DOI: 10.1016/j.advengsoft.2011.01.002

[25] MARTÍ-VARGAS, J.R.; FERRI, F.J.; YEPES, V. (2013). Prediction of the transfer length of prestressing strands with neural networks. Computers and Concrete, 12(2):187-209. DOI:10.12989/cac.2013.12.2.187

[26] C. INGRAO, A. MESSINEO, R. BELTRAMO, T. YIGITCANLAR, AND G. IOPPOLO, (2018) "How can life cycle thinking support sustainability of buildings? Investigating life cycle assessment applications for energy efficiency and environmental performance," J. Clean. Prod., vol. 201, pp. 556-569. Nov 2018

[27] L. F. CABEZA, A. CASTELL, M. MEDRANO, I. MARTORELL, G. PÉREZ, AND I. FERNÁNDEZ, (2010) "Experimental study on the performance of insulation materials in Mediterranean construction," Energy Build., vol. 42, no. 5, pp. 630-636, May 2010.

[28] J. SIERRA-PÉREZ, J. BOSCHMONART-RIVES, A. C. DIAS, AND X. GABARRELL, (2016) "Environmental implications of the use of agglomerated cork as thermal insulation in buildings" $J$. Clean. Prod., vol. 126, pp. 97-107, 2016. 